\title{
СОЦІОЛОГІЧНІ НАУКИ
}

УДК 316.74

DOI: 10.15587/2313-8416.2014. 27465

\section{МИСТЕЦЬКІ ГАЛЕРЕЇ ТА ЦЕНТРИ В УМОВАХ СУЧАСНОГО АРТ-РИНКУ}

\section{(C) O. А. Захарова}

Стаття присвячена актуальній проблемі - визначенню мистецьких галерей та арт-ияентрів як специфічного соціального простору. За результатами емпіричного дослідження розглянуто характер реклами мистецьких галерей та особливості культурних практик мешканців Києва; виділено низку особливостей сучасного украйнського арт-ринку та ряд сочіальних проблем, які гальмують його розвиток, потребують покращення та подальшого дослідження.

Ключові слова: арт-ринок, мистецька галерея, культурне споживання, арт-ияентр, сучасне мистецтво, реклама.

The article is devoted to the actual problem - the definition of art galleries and centers as a specific social space. According to the results of an empirical study the nature of advertising in galleries and cultural practices of residents of Kiev are examined; the features of Ukrainian art market and social problems that hinder its development are highlighted.

Keywords: Art market, art gallery, cultural consumption, art center, modern art, advertising.

\section{1. Вступ}

Арт-ринок, як соціально-економічний i культурно-історичний феномен, що представляє собою систему товарного обігу творів мистецтва, спосіб поширення та перерозподілу культурних цінностей у суспільстві в Україні знаходитися тільки на стадії свого зародження та розвитку. Художні твори все частіше розглядаються не тільки як духовні, але і як комерційні цінності.

Мистецькі галереї та центри виступають вагомими складовими арт-ринку, який, в свою чергу, представляє значний сектор у світовій економіці та здійснює істотний вплив на художнє життя суспільства. Цій проблемі в іiї соціологічному, історичному, культурологічному, економічному вимірах присвячені окремі дослідження, проте велика частина питань ще не стала предметом наукового аналізу, досі немає повної картини розвитку галерей та арт-центрів України. Необхідно відзначити, що розростання арт-ринкових інститутів, їх проникнення в структуру сучасної культури, взаємодія ринкових $\mathrm{i}$ художніх механізмів у системі споживання, активний розвиток творчих індустрій та реклами зробили вивчення мистецьких галерей та арт-центрів особливо важливими.

\section{2. Наукова проблема}

Наукова проблема, на вирішення якої спрямоване дане дослідження, полягає в суперечності між гносеологічною потребою розкриття особливостей розвитку художніх галерей та мистецьких центрів у полі сучасного арт-ринку та відсутності відповідних теоретичних розробок та емпіричного обгрунтованого знання в сучасній соціологічній науці.

\section{3. Рівень розробленості проблеми у науковій} літературі

Дослідження мистецьких галерей та артцентрів здійснювалось на основі наукових праць зарубіжних та вітчизняних вчених із соціології, культурології, філософії, реклами. Аналіз місця артринку як складової культури у повсякденні людини здійснювався на основі досліджень динаміки соціокультурних змін (А. Тоффлер, А. Моль, Г. Хубер, Ж. Бодрійяр, Л. Іонін, Н. Побєда), масової культури (Х. Ортега-і-Гассет, Т. Адорно, Г. Маркузе, О. Шпенглер, У. Еко, Е. Шилз, Г. Ашин, О. Кукаркін, Л. Лапокниш, В. Танчер), символічно-знакових систем як основи комунікації (Дж. Мід, П. Бурдьє, Ч. Пірс, Р. Барт, О. Лосєв, Ю. Лотман, Н. Костенко).

Були розглянуті праці 3 теорії та практики суспільства споживання (роботи Р. Барта, Ж. Бодрийяра, Т. Веблена, Г. Дебора, Г. Зіммеля, Г. Маркузе, Х. Ортеги-де-Гассета, Д. Рісмена, Е. Фромма; статті та монографії Б. Гройса, К. Каррьєра, Н. Т. Оганесян та ін.), які важливі для розуміння процесів, що визначають арт-ринок і його специфіку. Треба зазначити, що арт-ринок розглядався також у якості системи особливих 
соціальних інститутів французькими соціологами П. Бурдьє і А. Молем.

\section{4. Мета статті}

Виявити специфіку розвитку художніх галерей та мистецьких центрів у контексті інституціоналізації сучасного арт-ринку.

Для дослідження галерей та арт-центрів Києва було використано три методи збору емпіричних даних:

1. Серія напівструктурованих інтерв'ю 3 експертами у арт-сфері (кураторами, власниками галерей та арт-центрів; арт-дилерами; маркетологами, які працюють в сфері мистецтва).

2. Опитування відвідувачів галерей.

3. Контент-аналіз — візуальне дослідження рекламних анонсів виставок.

\section{5. Соціальні характеристики та інституціональні проблеми формування українського арт-ринку (за результатами експертного опитування)}

У вибірці дослідження арт-ринку представлено три кластери: арт-центри (як макро-рівень), мезогалереї та мікро-галереї. Такі кластери були сформовані за соціальними, економічними та функціональними показниками. Для опитування експертів був обраний метод напівструктурованого інтерв'ю. Експерти, які увійшли до вибірки:

Більшість інтерв'ю відбувалися при особистих зустрічах з експертами, тільки деякі опитування, у зв'язку 3 відсутністю територіального доступу до респондентів, відбулися в он-лайн режимі, за рахунок програми Skype. Під час проведення інтерв'ю відчувалися певні тенденції у думках експертів, вони залежали від прихильності респондентів до концептуального мистецтва та специфіки діяльності (рівня включенності у ринкові відносини), а саме приналежності до прибуткової або неприбуткової галерейної діяльності.

У визначенні сучасного мистецтва більшість думок експертів зводилось до понять:

1) концептуальне;

2) актуальне;

3) радикальне;

4) критичне.

Адже воно спрямоване на пошук больових моментів у суспільстві, саме взаємозв'язок мистецтва та життя ставить соціальні діагнози. Основні проблеми сучасного мистецтва мають фінансовий характер, оскільки приділяється мало уваги спонсоруванню, відсутня спеціалізована професійна освіта, спеціалізована преса та видання. Галереї при виборі художників користуються суб'єктивними чинниками: особистими смаками куратора, засновника або власника. Мають короткий життєвий цикл та часто неприбуткові. У той же час символічний капітал у мистецтві формує економічний: вартість картини визначає художній досвід автора, його участь в експозиціях, міжнародних бієнале та аукціонах. В Україні наявне непрозорі ціноутворення.
У рекламі мистецтва головну роль відіграють нові медіа. Соціальні мережі та «циганське радіо» стали одними 3 найважливіших каналів. Галерея таким чином виступає промоутером художника. Популярність художнього закладу залежить від стратифікованості аудиторії, соціальнодемографічних та гендерних особливостей, але їх тенденції носять хвильовий рух. Для масової аудиторії жанри традиційного мистецтва більш зрозумілі, адаптовані для масової свідомості. Успіх галереї залежить від регулярності проектів, групових експозицій, мобільності галереї та гнучкості простору. На думку Олександра Соловйова, 80 \% успіху митця - це робота медіа, але об'єктивність все ж таки присутня оскільки талант $\epsilon$ однією із складових. На Заході присутня машина арт-ринку, у нас він тільки зароджується, оскільки існує всього 20 років. У Європі арт ринок сформований у кластерах, але у нас він не структурований.

Питання на яке експерти давали найбільш протилежні думки - це встановлення відношення між ринком та мистецтвом (питання "Як Ви вважаєте мистецтво впливає на ринок чи ринок на мистецтво?”). Чи знаходяться ринок та мистецтво у взаємодіï? На одну з думок експертів (Олександр Соловйов) вони ірраціональні та не корелюють, в той час Ольга Музиченко зазначає, що вони знаходяться у постійній взаємодії.

Висновки інтерв'ю з експертами:

1. Український арт-ринок не сформований.

2. Реклама є важливою, але для неї в першу чергу потрібен не економічний, а соціальний капітал та технічне забезпечення.

3. Галерея сфокусована на економічній функції на відміну від арт-центру, для якого головною $\epsilon$ освітня функція.

4. Основні проблеми українського арт-ринку: відсутність професійної освіти, слабка фінансова підтримка, відсутність розвинутої спеціалізованої преси.

5. Відсутні чіткі критерії визначення якості художнього твору.

6. Існує соціальний розкол між традиційними формами та концептуальним мистецтвом.

7. Престиж - основний критерій розвитку художника. Фактори, які формують високий соціальний статус художника: участь в аукціонах та міжнародних виставках.

8. У суспільстві присутня довіра до міжнародних імен, в той час як до сучасних українських художників вона відсутня.

9. Причина швидкого розвитку сучасного концептуального мистецтва у довготривалій радянській забороні.

10. Реклама мистецтва виконує три основних функції: інформаційну, просвітницьку та інтеграційну.

11. Соціальна комунікація та інтеракція - $€$ активною діяльністю арт-центрів, але ці явища слабо розвинуті у сучасних українських галереях.

12. Інтернет - основний канал реклами у розвитку культурного сегменту. 
13. Соціальні групи, які відвідують мистецькі заклади неоднорідні, найчастіше їх характеристики залежать від специфіки окремої галереї. У кожного арт-центру та галереї є свій портрет споживача.

14. В Україні поки що не сформувалися художні кластери.

15. Культурне життя розвивається швидко, але його формують не професіонали у даній сфері діяльності, а стихійні кризові обставини.

6. Особливості та мотивація культурного споживання відвідувачів галерей та арт-центрів (за результатами анкетування)

Другим етапом дослідження стало анкетування відвідувачів галерей. Для апробації методу досліджування було проведено анкетування 60 відвідувачів київських центрів мистецтва.

Більшість відвідувачів галерей вважають галереї та арт-центри - сучасним осередком культури (54 \%), у той час як такі визначення галереї як «освітній заклад», «дозвілева установа» майже не представлені серед думаок респондентів (8 та $10 \%$ ) (рис. 1). Тому постає питання, які функції виконує культура на думку сучасних відвідувачів та які критерії та особливості сучасної культури.

Особливості вибіркової сукупності відвідувачів галерей та арт-центрів: середній вік респондента у склав 28 років, респонденти майже рівномірно розподілені за гендерним аспектом (43\% чоловіки та $57 \%$ жінки). Більше половини опитаних мають повну робочу зайнятість (68 \% відповідно), п’ята частина вибіркової сукупності не працює, 12 \% респондентів має часткову зайнятість.

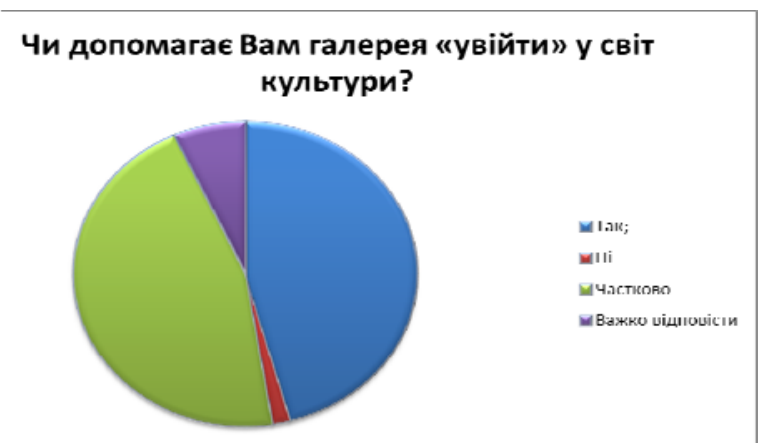

Рис. 1. Роль галерей у культурі на думку відвідувачів

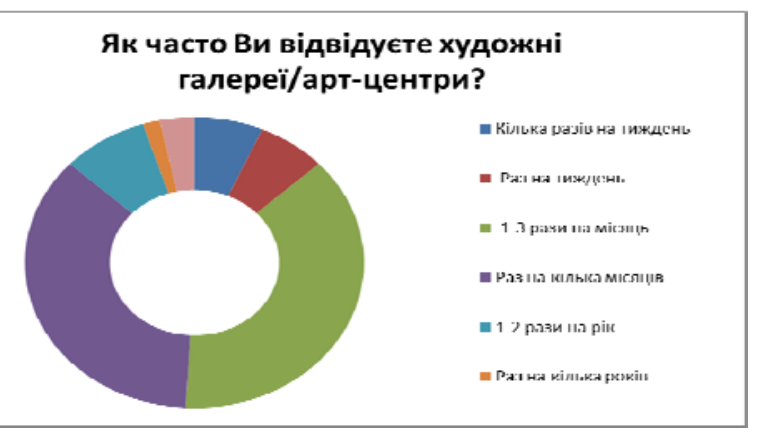

Рис. 2. Частота відвідування галерей та арт-центрів
Сучасний відвідувач слабо освічений щодо культурних закладів столиці, найчастіше респонденти згадували серед знайомих галерей: музеї, Пінчук арт-центр та Андріївський узвіз. Тому на базі невеликої вибіркової сукупності можна стверджувати про відсутність сформованого образу цілей та функцій галерей серед відвідувачів. Найчастіше серед відомих галерей відвідувачі згадували Мистецький Арсенал та Пінчук Арт центр. Тому можна казати, що присутня позитивна тенденція серед культурних практик громадян, оскільки арт-центри більш відомі серед населення, ніж комерційні галереї. Хоча в той же час це підтверджує наявну проблематику у не сформованості та непродуктивності галереї, як соціального утворення та культурного закладу.

Сучасні відвідувачі більше довіряють порадам друзів, ніж засобам масової інформації (рис. 4). Цей феномен можна пояснити тим, що більшість респондентів вважають, що саме думки відвідувачів визначають «справжність» мистецтва (рис. 5). Щодо визначення мистецтва та функцій ринку у формуванні вартості твору думки власників галерей та їх відвідувачів виявилися різними (рис. 3).

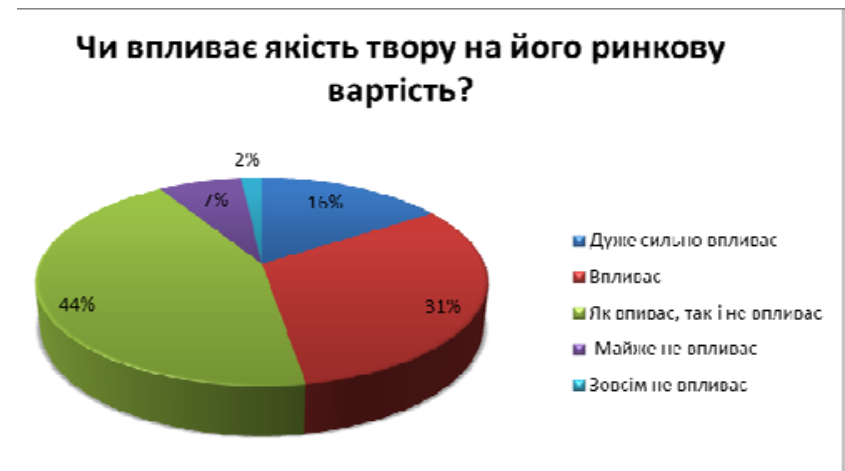

Рис. 3. Взаємозвязок якості твору з його ринковую ціною

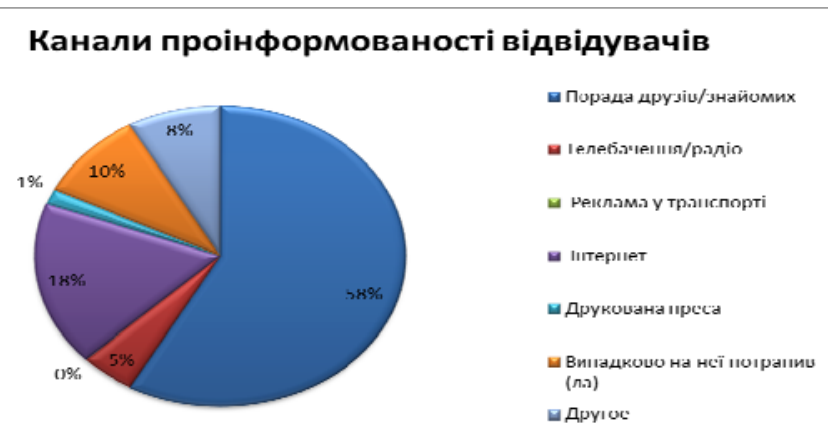

Рис. 4. Причини відвідування галерей та арт-центрів

Думки експертів та відвідувачів зійшлися щодо основних рекламних каналів, якими наразі виступає Інтернет, а саме соціальні мережі (рис. 6). 


\section{Справжнє мистецтво визначають:}

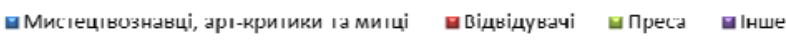

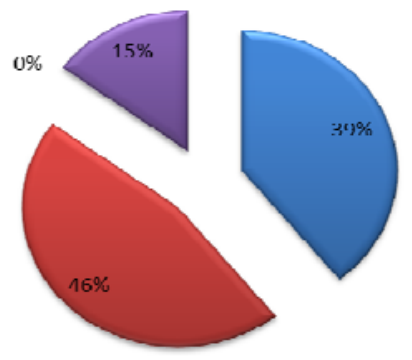

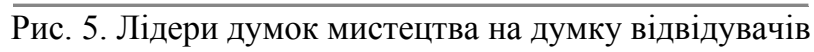

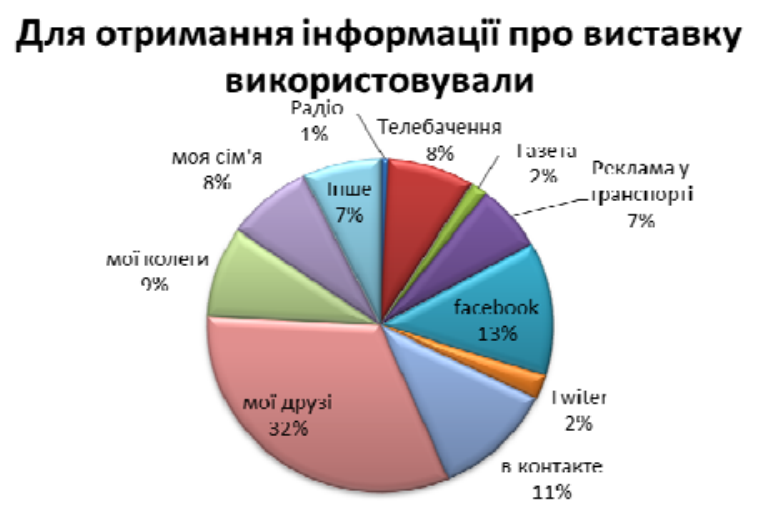

Рис. 6. Основні канали інформації

7. Акцентуалізація рекламних анонсів мистецьких галерей та арт-центрів (за результатами контент-аналізу)

На третьому етапі дослідження було проаналізовано більше ста афіш відомих галерей та арт-центрів Києва. Виявлено, що галереї часто використовують абстрактні зображення без стимулюючого або інформативного тексту. Звідси постає головна проблема, що сучасний мешканець Києва не усвідомлює, що саме його очікує на виставці і не має сформованого образу мистецьких течій. Було доведено, що більшість рекламних зображень використовують абстрактний жанр: лінії, кольорові плями, геометричні фігури. Присутня кореляція між змістом зображення та текстом тільки в афішах Мистецького Арсеналу, це можна пояснити тим, що це на разі єдиний виставковий простір, який контролюється i фінансується державою, використовує свої афіші у публічному транспорті.

Сучасні афіші галерей більше подібні до симулякрів у розумінні Ж. Бодріяйра, оскільки їх зміст майже не співвідноситься назвою події, тим самим рекламна афіша не несе відображення реальності, викликає фрустрацію.

Ще один важливий момент помічений у дослідженні - це відсутність специфічної символіки, притаманних національному або європейському вектору (різним культурам), це можна пояснити процесами глобалізації, які наявні в сучасному мистецькому суспільному дискурсі. В той самий час тексти, які не дивлячись на їх рідке використання в афішах, зустрічаються як українською так i англійською мовою, що свідчить про орієнтацію сучасного мистецтва на міжнародну культурну арену. Символікою тієї чи іншої країни свідчить тільки використання україномовних або англійськомовних текстів.

Крім цього було виявлено, що у кожної галереї присутні свої тенденції у символіці та використовуваних жанрах (табл. 1).

Таблиця 1

Особливості рекламних афіш художніх галерей

\begin{tabular}{|l|l|}
\hline \multicolumn{1}{|c|}{ Назва арт-центру/галереї } & \multicolumn{1}{|c|}{ Особливості візуалізації реклами } \\
\hline M17 & Найчастіше використовують графічний дизайн та англомовні тексти \\
\hline Bottega & Абстрактні афіші з мінімалістичною колористикою \\
\hline Гретера & Досить часто використовують портрети людей \\
\hline Мистецькій Арсенал & Використовують текстовий формат афіш, інформативного характеру \\
\hline Я галерея & Використовують зображення оголеного тіла \\
\hline
\end{tabular}

Оголене тіло представлено майже в усіх мистецьких закладах (у державних рідше), найчастіше зображення вище тулуба людини, яке несе асексуальний характер. Важливо наголосити, що в останні роки відбувається зниження вибуху використання оголеного тіла у мистецтві, який був наявний після розпаду Радянського Союзу (рис. 7).

Основна проблематика, яка була помічена у ході дослідження виникає з того, що афіші рідко дають уявлення про виставку. До того ж у кожної галереї сформувався свій вектор формування рекламного зображення. На приклад, у «Боттезі» вони несуть нейтральній характер, оскільки колористика складається тільки 3 кількох кольорів, жанр робіт абстрактний. Афіша втрачає інформативну та естетичну функціональність. У «Гретери» 85 відсотків наявних зображень портрети людей, в той час як М17 використовує графічний дизайн та текстові формати, «Я-галерея» символічні зображення. Тому можна говорити про індивідуалізованість галерей, суб'єктивність мистецтва, що негативно впливає на його просвітницьку функцію серед населення. Сучасне мистецтво нині формується в площині масової культури. Це означає, що в його розвитку головною функцією $є$ функція соціальної детермінації, оскільки його соціокультурні функції потерпають від змін у бік інтелектуалізації людини та світу та соціалізації людини. Отже, мистецтво $є$ дзеркалом, яке відображає суспільство, воно формує моделі 
поведінки, як позитивні, так і негативні, тому стає особливо доцільно досліджувати особливості рекламних афіш мистецьких центрів, кульурні практики відвідувачів, думки лідерів та експертів, які формують соціальне поле мистецтва.

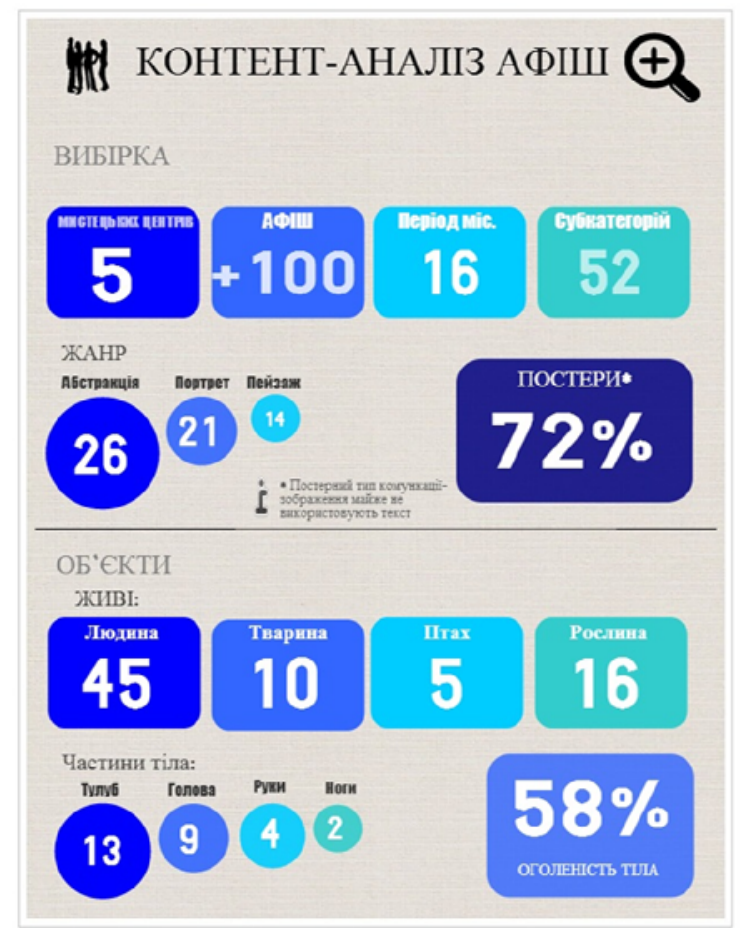

Рис. 7. Інфографіка за результатами дослідження рекламних афіш галерей

\section{8. Висновки}

Комплексне дослідження галерей та артцентрів у поєднанні кількісних та якісних методів довело наявну проблематику у функціонуванні та рекламуванні галерей та арт-центрів.

По-перше, необхідно відзначити, що галереї та арт-центри різні за своїм соціальними функціями та соціальним середовищем. Галерея - більш комерційне утворення, має вже сформовану клієнську базу завдяки соціальному престижу, капіталу, участі в аукціонах та бієналє. У той самий час українські арт-центри в першу чергу зацікавлені у просвітницькій та освітніх функціях. Обидва типи мистецьких закладів наразі виконують функцію соціальної інтеграції, але арт-центри саме через велику мобільність (як простору так і подій) та активне використання реклами більш популярні серед населення. За результатами експертних інтерв'ю було виявлено, що молодь - найбільш типовий відвідувач галереї, тому на разі стає дуже важливим контроль тієї інформації, яку надають сучасні арт-центри та галереї, оскільки вони формують не тільки уявлення про мистецтво, але й про рівень культури суспільства в цілому. Тут i постає друга глобальна проблема розвитку українських галерей та арт-центрів - брак ресурсів, як фінансових так і освітніх. Мистецький Арсенал єдиний центр та галерея, який отримує фінансову підтримку від держави, вимушений брати кошти за вхід. Пінчук Арт Центр, як показали результати опитування, один 3 найбільш відомих арт-центрів серед населення, не виниконує рекреаційну функцію, а спрямований на актуалізацію сучасних суспільних проблем i може бути визначений більше як соціологічна, ніж мистецька установа. Як раз цей артцентр і є підтвердженням ідеї сучасної соціологині А. Ейніш, оскільки, як вона зазначає, сучасні художники перетворилися більше на соціологів, ніж митців.

Опитування відвідувачів відкрило третю проблему українського арт-ринку - слабку культурну освіченість жителів міста. Оскільки більшість відвідувачів у кращому випадку знайома 3 1-2 артцентрами міста, зовсім не має уявлення про функціонування сучасних галерей. Крім цього варто зазначити, що у сучасного споживача культури не тільки відсутнє уявлення про галереї у столиці, але й відсутнє визначення та розуміння, що таке “галерея", більшість респондентів вважають Андріївський узвіз - галереєю мистецтва. Що до частоти культурних практик, то як свідчить апробація дослідження респонденти найчастіше відвідують галереї раз на місяць. Основною мотиваціюю для відвідування подій $є$ порада друзів, найбільш впливою є реклама у соціальних мережах.

У сучасному соціумі contemporary art - це не просто мистецтво, створене сучасниками, це мистецтво актуальне - репрезентація суспільної проблематики та структури. Сучасне мистецтво $є$ активно рефлексуюче мистецтво, яке потрібно осягати знову i знову. 3 аналізованого матеріалу тільки арт-центри (М17, «Мистецький Арсенал», «Я. Гретера») мають афіші спрямовані на соціальну інтеракцію та виконують просвітницьку функцію. У той час як афіші галерей («Я-Галерея», «Боттега») втрачають соціальну значущість, мають абстрактний характер, дисфункціональні та суб'єктивні за своїм змістом Отже, проаналізувавши акценти рекламних афіш галерей можна стверджувати, що рекламні афіші у галереях потребують вдосконалення, адаптацію до світових критеріїв культурної політики та соціальної комунікації.

Питання, яке залишається актуальним для подальшого соціологічного дослідження - це взаємодія мистецтва та ринку, культурного та економічного капіталу українського суспільства. Оскільки, як показало дослідження, ця взаємодія викликає найбільше протиріччя серед думок експертів та відвідувачів. Важко визначити чи це $є$ однобічний вплив, чи ці два поля знаходяться у взаємовпливі, думки експертів виявилися протилежні. На нашу думку, як раз розуміння співвідношення цих двох полів $\epsilon$ актуальним, оскільки питання домінанти у формуванні сфери культурного, iï вивчення та дослідження може покращити, як культурні практики громадян, так i мистецьку політику держави в цілому, підняти культурну планку суспільства на новий рівень.

\section{Література}

1. Барт, Р. Рекламное сообщение [Текст] / Р. Барт; пер. с фр. - Система моды. Статьи по семиотике культуры. - М.: Издательство им. Сабашниковых, 2003. C. $410-415$. 
2. Беньямин, В. Произведение искусства в эпоху его технической воспроизводимости [Текст] / В. Беньямин. М.: Медиум, 1996. - С. 45-51.

3. Бодрийяр, Ж. К критике политической экономии знака [Текст] / Ж. Бодрийяр. - М.: Библион-Русская книга, 2003. -145 c.

4. Бурдье, П. Рынок символической продукции [Текст] / П. Бурдье // Вопросы социологии. -1993.№ 1/2. - С. 51-52.

5. Глаголев, А. И. О маркетинге в культуре [Текст] / А. И. Глаголев, Р. М. Пискотина // Социальноэкономические проблемы художественной культуры. М., 1987. - C. 89-97.

6. Глотов, М. Б. Художественная культура как система социальных институтов [Текст] : автореф. ... канд. дис. / М. Б.Глотов. - JL, 1974. - С. 123-126.

7. Гройс, Б. О музее современного искусства [Текст] / Б. О Гройс // Художественный журнал. - 1998. № 23. - С. 15-21.

8. Груен, Н. Концептуализируя художественный рынок [Текст] / Н. Груен // Новый мир искусства. - 2001. № 4. - C. 29-31.

9. Гуревич, ЈI. Объявление о смерти. Читая новую арт-критику [Текст] / ЈI. Гуревич // Звезда. - 2001. - № 3. C. 207-212.

10. Манхейм, К. Избранное: социология культуры [Текст] / К. Манхейм; пер. с англ. -М.: Университетская книга, 2000. - С. 78-92.

11. Мозговая, Ж. Галереи в условиях современного художественного рынка [Текст] / Ж. Мозговая. Дипломная работа. СПбГУП, 2001. - 63 с.

12. Моль, А. Социодинамика культуры [Текст] / А. Моль. - М., 1973. - С. 263-268.

13. Савельева, О. О. Социология рекламного воздействия [Текст] / О. О. Савельева. - М.: «РИПхолдинг», C12, 2006. - $284 \mathrm{c}$.

14. Суворов, Н. Н. Галерейное дело: Искусство в пространстве галереи [Текст] / Н. Н. Суворов. - СПб.: Издво С.-Петерб. ун-та, 2006. - 201 с.

15. Alexander, V. D. Sociology of the Arts. Exploring Fine and Popular Forms [Text] / V. D. Alexander. - Oxford: Blackwell Publishing, 2003. - P. 124-126.

16. Heinich, N. Ce que la sociologie fait a l'art contemporain (entretien avec Frederique Matonti et Anne Simonin) [Text] / N. Heinich // Societes et representations. 2001. - Vol. 11, Issue 1. - P. 311-323. doi: $10.3917 / \mathrm{sr} .011 .0311$

17. Heinich, N. La sociologie de l'art [Text] / N. Heinich. - Paris, Éd. La Découverte, coll. Repères, 2001. $123 \mathrm{p}$.

18. Schirato, T. Communication and culture [Text] / T. Schirato, S. Yell. - London: Sage Publications, 2000. $204 \mathrm{p}$.

\section{References}

1. Bart, R. (2003). Reklamnoe soobshhenie. Sistema mody. Stat'i po semiotike kul'tury. [Advertising message. System mode. Articles on the semiotics of culture]. Moscow, Publisher behalf Sabashnikovyh, 410-415.

2. Ben'jamin, V. (1996). Proizvedenie iskusstva v jepohu ego tehnicheskoj vosproizvodimosti [Art Works in the Age of Their Techanical Reproduction]. Moscow, Medium, 240.

3. Bodrijjar, Zh. (2003). K kritike politicheskoj jekonomii znaka [Critique of Political sign]. Moscow, Biblion Russian book, 145.

4. Burd'e, P. (1993). Rynok simvolicheskoj produkcii [Market symbolic production]. // Questions of Sociology, 1/2, 51-52.

5. Glagolev, A. I., Piskotina R. M. (1987). O marketinge $\mathrm{v}$ kul'ture [On marketing in the culture]. Socio - economic problems of artistic culture. Moscow, 89-97.

6. Glotov, M. B. (1974). Hudozhestvennaja kul'tura kak sistema social'nyh institutov [Artistic culture as a system of social institutions]. Abstract of $\mathrm{PhD}$ dissertation JL, 123-126.

7. Grojs, B. O (1988). O muzee sovremennogo iskusstva [About the Museum of Modern Art]. Moscow Art Magazine, $23,15-21$.

8. Gruen, N. (2001). Konceptualiziruja hudozhestvennyj rynok [Conceptualizing the art market]. New World of Art, 4, 29-31.

9. Gurevich, J. I. (2001). Ob'javlenie o smerti. Chitaja novuju art-kritiku [The announcement of the death. Reading the new art criticism]. Star, 3, 207-212.

10. Manhejm, K. (2000). Izbrannoe: Sociologija kul'tury. [Favorites: Sociology of culture]. St. Petersburg, University Book, 501.

11. Mozgovaja, Zh. (2001). Galerei v uslovijah sovremennogo hudozhestvennogo rynka [Galleries in today's art market]. Thesis. SPbGUP, 63.

12. Mol', A. (1973). Sociodinamika kul'tury [Sociodynamics culture]. Moscow, 263-268.

13. Savel'eva, O. O. (2006). Sociologija reklamnogo vozdejstvija [Sociology of advertising exposure]. Moscow , «RIP-holding», 284.

14. Suvorov, N. N. (2006). Galereĭnoe delo: Iskusstvo v prostranstve galerei [The gallery business: Art in the gallery space]. St. Petersburg, Publisher St. St. Petersburg University, 201.

15. Alexander, V. D. (2003). Sociology of the Arts. Exploring Fine and Popular Forms. Oxford, Blackwell Publishing, 124-126.

16 Heinich, N. (2001). Ce que la sociologie fait a l'art contemporain (entretien avec Frederique Matonti et Anne Simonin). Societes et representations, 11 (1), 311-323. doi: $10.3917 /$ sr.011.0311

17. Heinich, N. (2001). La sociologie de l'art. Paris, Éd. La Découverte, coll. Repères, 123.

18. Schirato, T., Yell, S. (2000). Communication and culture. London: Sage Publications, 204.

Рекомендовано до публікації д-р філ. наук Набруско І. Ю. Дата надходження рукопису 19.09.2014

Захарова Олександра Артемівна, кафедра соціальних структур та відносин, КНУ імені Тараса Шевченка , просп. Академіка Глушкова 4д, м. Київ, 03680, Україна

E-mail: phozanet@gmail.com 